
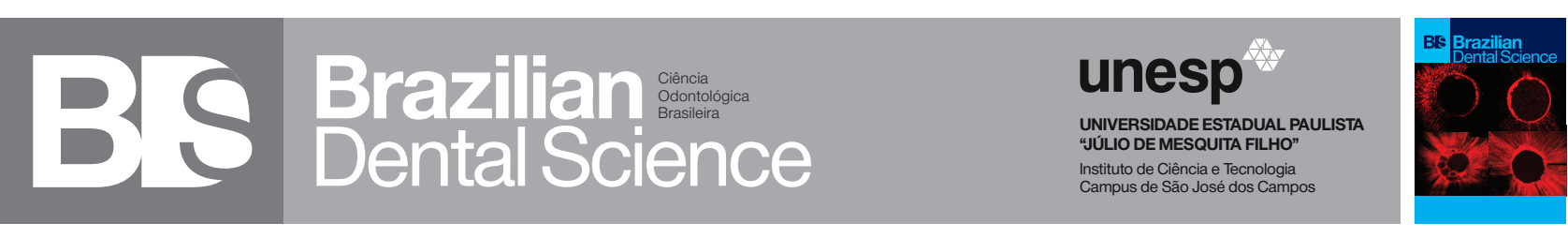

\title{
Fracture resistance of teeth obturated with two different types of mineral trioxide aggregate cements
}

\author{
Resistência à fratura de dentes obturados com dois tipos diferentes de cimentos agregados de trióxido mineral
}

\author{
Nidambur Vasudev BALLAL ${ }^{1}$, Sheetal RAO ${ }^{1}$, Junsang YOO $^{2}$, Kishore GINJUPALLI ${ }^{3}$, Manuel TOLEDANO ${ }^{4}$, Nadin AL-HAJ HUSAIN ${ }^{5}$, Mutlu \\ ÖZCAN $^{6}$ \\ 1 - Department of Conservative Dentistry \& Endodontics - Manipal College of Dental Sciences, Manipal, Manipal Academy of Higher Education, \\ Manipal, Karnataka, India. \\ 2 - Seoul National University School of Dentistry - Seoul - Korea. \\ 3 - Department of Dental Materials - Manipal College of Dental Sciences, Manipal, Manipal Academy of Higher Education, Manipal, \\ Karnataka, India. \\ 4 - University of Granada - Faculty of Dentistry - Dental Materials Section - Colegio Máximo de Cartuja s/n - 18071 Granada - Spain. \\ 5 - Department of Reconstructive Dentistry and Gerodontology - School of Dental Medicine - University of Bern - Switzerland. \\ 6 - Division of Dental Biomaterials, Clinic for Reconstructive Dentistry - Center for Dental and Oral Medicine - University of Zurich - Zurich \\ - Switzerland.
}

\section{ABSTRACT}

Objective: Endodontically obturated teeth have lower fracture resistance depending on the obturating material and technique. The purpose of this study was therefore to evaluate the influence of ProRoot MTA (Dentsply Sirona, Tulsa Division) and OrthoMTA III (BioMTA, Daejeon, Korea) as an obturating material on the fracture resistance of endodontically treated teeth. Material and Methods: Thirty extracted human maxillary central incisors were decoronated and instrumented using Protaper instruments (size F5). Irrigation was performed with $2.5 \%$ sodium hypochlorite between each instrument change followed by $7 \%$ maleic acid for one minute. Finally, canals were flushed with 5 $\mathrm{ml}$ of PBS solution for one minute. Samples were then divided into three groups. Group I- positive control (no root canal filling); Group II- obturation with ProRoot MTA; Group III- obturation with OrthoMTA III. Ten teeth were randomly selected as a negative control in which no treatment was performed. All the specimens were then subjected to fracture strength testing using universal testing machine. For evaluation of biomineralization, six maxillary central incisors were divided into two groups. Group I obturated with ProRoot MTA and group II obturated with OrthoMTA III. These samples were subjected to SEM analysis. Results: Positive control group demonstrated the least fracture resistance, while OrthoMTA III group showed the highest fracture resistance. There was no significant

\section{RESUMO}

Objetivo: Dentes obturados endodonticamente apresentam menor resistência à fratura,dependendo do material e da técnica de obturação. Portanto, o objetivo deste estudo foi avaliar ainfluência do ProRoot MTA (Dentsply Sirona, Tulsa Division) e OrthoMTA III (BioMTA, Daejeon, Coréia) como material obturador na resistênciaà fratura dedentes tratadosendodonticamente. Material e Métodos: Trinta incisivos centrais superiores humanos extraídosforam decoronados e instrumentados com instrumentos Protaper (tamanho F5). A irrigação foirealizada com hipoclorito de sódio a 2,5\% entre cada troca de instrumento, seguida por ácidomaleico a 7\% por um minuto. Finalmente, os canais foram lavados com $5 \mathrm{ml}$ de solução de PBSpor um minuto. As amostras foram então divididas em três grupos. Grupo I - controle positivo(sem preenchimento do canal radicular); Grupo II - obturação com ProRoot MTA; Grupo III -obturação com OrthoMTA III. Dez dentes foram selecionados aleatoriamente como controlenegativo, no qual nenhum tratamento foi realizado. Todas as amostras foram então submetidas atestes de resistência à fratura usando uma máquina de teste universal. Para avaliação dabiomineralização, seis incisivos centrais superiores foram divididos em dois grupos: grupo Iobturado com ProRoot MTA e grupo II obturado com OrthoMTA III. Essas amostras foramsubmetidas à análise SEM. Resultados: O grupo controle positivo demonstrou a menorresistência à fratura, enquanto o grupo OrthoMTA III apresentou a maior resistência à fratura.Não houve diferença significativa entre o 
difference between negative control group and ProRoot MTA groups $(p=0.821)$. OrthoMTA III group showed better tubular biomineralization when compared to ProRoot MTA. Conclusions: Root canals obturated with OrthoMTA III had better fracture resistance and increased tubular biomineralization compared to ProRoot MTA. Since root canals obturated with OrthoMTA III had better fracture resistance, it can be used as a promising obturating material.

\section{KEYWORDS}

Biomineralization; Fracture Resistance; OrthoMTA III; ProRoot MTA; Root Canal; Tubular. grupo controle negativo e os grupos ProRoot MTA $(p=0,821)$. O grupo OrthoMTA III apresentou melhor biomineralização tubular quandocomparado ao ProRoot MTA. Conclusões: Os canais radiculares obturados com OrthoMTA IIIapresentaram melhor resistência à fratura e maior biomineralização tubular em comparação como ProRoot MTA. Como os canais radiculares obturados com OrthoMTA III apresentarammelhor resistência à fratura, podendo ser utilizado como um material obturador promissor.

\section{PALAVRAS-CHAVE}

Biomineralização; Resistência à Fratura; OrthoMTA III; ProRoot MTA; Canal radicular; Tubular.

\section{INTRODUCTION}

T $\mathrm{t}$ has been widely considered that Lendodontically treated teeth are more 4]. This is because endodontic procedures can result in structural and chemical changes of root canal dentin that render the tooth prone for vertical root fracture (VRF). There are several factors which are responsible for the brittleness of endodontically treated teeth. Endodontic procedures include caries excavation, access cavity preparation and root canal instrumentation, which obviously result in loss of tooth structure. Apart from this loss, tooth biomechanics are altered when root canals are irrigated with various irrigating agents and also by the prolongued placement of intracanal medicaments. Other factors such as obturation techniques and post placements have also been associated with vertical root fracture in endodontically treated teeth [5-7].

One approach to prevent VRF in endodontically treated teeth is to reinforce the residual tooth structure by the root canal filling material [8]. The use of gutta-percha and sealers has remained the standard of care for obturating the root canal in endodontics in spite of its poor adhesion to the dentinal walls of the root canal system $[9,10]$. Recently, it has been suggested that mineral trioxide aggregate (MTA) was able to produce a tight seal with the root dentin walls that was superior to many other existing materials $[11,12]$. MTA is hydraulic cement that consists of fine hydrophilic particles of tricalcium oxide, tricalcium silicate, bismuth oxide, dicalcium silicate, tricalcium aluminate, and calcium sulfate dehydrate. In the presence of water or moisture it forms a colloidal gel that solidifies to form hard cement. However, the ability of MTA to strengthen the tooth structure has been studied with controversial results. White et al. demonstrated weakening of dentinal structure in short term and attributed this effect to the structural alteration of proteins caused by the alkalinity of MTA [13]. Andreasen et al. did not find a significant increase in fracture strength when immature sheep teeth were filled with MTA and compared with control (without filling) teeth [14]. Conversely, a strengthening effect of MTA has been shown in other studies $[15,16]$.

OrthoMTA (BioMTA, Daejeon, Korea) is a newly developed calcium silicate cement which is known to have shorter setting times ( $5 \mathrm{~h} 30 \mathrm{~min}$ ) and less heavy metal content $[17,18]$ when compared to ProRoot MTA (Dentsply Sirona, Tulsa Division). Furthermore, the heavy metal content of Ortho MTA was reported to be lower than that of ProRoot MTA [19]. Chang et al. 
[17] has revealed that, ProRoot MTA contained traces of arsenic (1.16 ppm), whereas Ortho MTA did not. According to the manufacturer, OrthoMTA prevents microleakage by forming an interfacing layer of hydroxyapatite between the material and the canal wall. Furthermore, it releases calcium ions through the apical foramen, which may induce regeneration of the apical periodontium [20]. Yoo et al. reported that, the OrthoMTA-PBS paste has an antibacterial effect in infected root canals [21]. Recently, OrthoMTA III (BioMTA) has been has been launched. Zirconium oxide has been used a radiopacifier to prevent tooth discoloration compared to the older version of OrthoMTA, which contained bismuth oxide as radiopacifier. The main composition of ProRoot MTA is Tricalcium silicate, $(\mathrm{CaO}) 3 \mathrm{SiO} 2 ;$ Dicalcium silicate, $(\mathrm{CaO}) 2 \mathrm{SiO} 2$; Tricalcium aluminate, (CaO)3 Al2O3; Tetracalcium aluminoferrite, (CaO)4 Al2O3 Fe2O3; Gypsum, CaSO4\$2H2O; Free calcium oxide, $\mathrm{CaO}$; and Bismuth oxide, $\mathrm{Bi} 2 \mathrm{O} 3$

The hydration reactions of ProrootMTA can be explained as follows:

(A) 2 [3CaO. $\left.\mathrm{SiO}_{2}\right]+6 \mathrm{H}_{2} \mathrm{O} \rightarrow 3 \mathrm{CaO}$. $2 \mathrm{SiO}_{2} \cdot 3 \mathrm{H}_{2} \mathrm{O}+3 \mathrm{Ca}(\mathrm{OH})_{2}$

(B) $2\left[2 \mathrm{CaO} . \mathrm{SiO}_{2}\right]+4 \mathrm{H}_{2} \mathrm{O} \rightarrow 3 \mathrm{CaO} .2 \mathrm{SiO}$. $3 \mathrm{H}_{2} \mathrm{O}+\mathrm{Ca}(\mathrm{OH})_{2}$

The main composition of OrthoMTA III is Tricalcium silicate, $(\mathrm{CaO}) 3 \mathrm{SiO} 2$; Dicalcium silicate, $\mathrm{CaO}) 2 \mathrm{SiO} 2$; Tricalcium aluminate, $(\mathrm{CaO}) 3 \mathrm{Al2O} 3$; Tetracalcium aluminoferrite, (CaO)4 Al2O3 Fe2O3; Free calcium oxide, $\mathrm{CaO}$; and Zirconium oxide, $\mathrm{ZrO} 2$

The hydration reactions of OrthoMTA III can be explained as follows: [22]

(A) $2\left[3 \mathrm{CaO} \cdot \mathrm{SiO}_{2}\right]+6 \mathrm{H}_{2} \mathrm{O} \rightarrow 3 \mathrm{CaO}$. $2 \mathrm{SiO}_{2} \cdot 3 \mathrm{H}_{2} \mathrm{O}+3 \mathrm{Ca}(\mathrm{OH})_{2}$

(B) $2\left[2 \mathrm{CaO} \cdot \mathrm{SiO}_{2}\right]+4 \mathrm{H}_{2} \mathrm{O} \rightarrow 3 \mathrm{CaO}$. 2SiO. $3 \mathrm{H} 2 \mathrm{O}+\mathrm{Ca}(\mathrm{OH}) 2$
(C) $6 \mathrm{CaHPO}_{4} \cdot 2 \mathrm{H}_{2} \mathrm{O}+3 \mathrm{Ca}(\mathrm{OH})_{2} \rightarrow$ $\mathrm{Ca} 9(\mathrm{HPO} 4)(\mathrm{PO} 4) 5(\mathrm{OH})+17 \mathrm{H}_{2} \mathrm{O}$

To date, no studies have evaluated the efficiency of OrthoMTA III in reinforcing the endodontically treated teeth when used as an obturating material. Hence, the aim of this study was to evaluate the influence of ProRoot MTA and OrthoMTA III as an obturating material on the fracture resistance of endodontically treated teeth. This study also investigated and compared the biomineralization ability of ProRoot MTA and OrthoMTA III cements when used as a root filling material. The null hypothesis tested was that there was no influence of either obturating material on the fracture resistance of root canal treated teeth.

\section{MATERIAL AND METHODS}

Ethical clearance for the use of human teeth for the experiment performed in the present study was obtained from the institutional review board (IEC 575/2016). Forty extracted human central incisors with similar dimensions were used. The teeth were cleaned and stored in $0.2 \%$ sodium azide (Millipore Sigma) at $4^{\circ} \mathrm{C}$ until the experiment. The teeth with carious lesions, cracks or fractures (examined using magnifying loupes) were eliminated. Buccolingual and mesiodistal radiographs were taken to confirm the presence of a single canal and to demonstrate that the teeth had similar internal anatomy. The mesiodistal and buccolingual dimensions of the teeth were determined at cementoenamel junction (CEJ) by using a gauge and teeth with similar dimensions was used in the study.

The teeth were decoronated at CEJ using a water-cooled diamond disc (Horico Dental) at low speed, and the length of the root was standardized to $16 \mathrm{~mm}$. Ten teeth were randomly selected as negatives controls, in which no further treatment was performed. For the remaining 30 teeth, apical patency was established using \#10 K file (Mani Inc.). The 
working length was established by inserting a No.10K file into each root canal until it was just visible at apical foramen (observed under magnifying loupes); and by then subtracting 1 $\mathrm{mm}$ from this length. Subsequently, canals were prepared to size F5 using Protaper instruments (Dentsply Maillefer). Irrigation was performed with $5 \mathrm{ml}$ of $2.5 \% \mathrm{NaOCl}$ (Vista Dental Inc) between each instrument change for one minute followed by $5 \mathrm{ml}$ of $7 \%$ maleic acid (KMC Pharmacy) for one minute. Finally the canals were flushed with $5 \mathrm{ml}$ of PBS solution ( $\mathrm{pH}$ 7.4) for one minute $[23,24]$.

All the irrigation was performed using 30 gauge side vented needle (Vista Dental Inc, USA) placed 1-2 mm short of working length. Then the specimens were randomly divided into three groups $(n=10)$, according to the obturation material used. Group I- positive control (no root canal filling); Group II- ProRoot MTA (Dentsply Sirona, Tulsa Division); Group III- OrthoMTA III (BioMTA, Daejeon, Korea).

In group II and III, MTA powder was mixed following the manufacturer's instructions. MTA was then be inserted into the root canals using MTA carrier and condensed incrementally using pluggers leaving the coronal $2 \mathrm{~mm}$ of the canal unfilled. A glass slab was used to prevent the extrusion of MTA from the apex. All the teeth were radiographed to verify the homogeneity of the fillings. Coronal access cavities were then sealed with glass ionomer cement (Fuji II, GC Inc) and the specimens were stored at $37^{\circ} \mathrm{C}$ and $100 \%$ relative humidity for $48 \mathrm{~h}$.

Periodontal ligament (PDL) simulation was performed by the modified method of Soares et al. [25] The roots were coated with a thin layer of moulding wax of 0.3-0.5 mm thickness up to $2.0 \mathrm{~mm}$ below the CEJ. The roots were then embedded in polystyrene resin (Dentsply) using polyvinyl chloride cylinders (PVC). After resin polymerization, the teeth were removed from the PVC cylinders, and the wax was removed from root surface and resin cylinder using hot water. The resin cylinders were then filled with a polyether impression material (3M ESPE) using a syringe and the roots were then re-inserted into their respective cylinder 'sockets' to simulate the periodontal ligament. Excess of the impression material was removed using a scalpel blade. The specimens were mounted in a universal testing machine (Instron 3366, Instroncorp). Vertical loads were transmitted to the roots using a 4-mm-diameter steel ball attached to a steel cylinder fitted on to the universal testing machine. Each acrylic block with its embedded root was fitted on a steel jig in a central position in such a way that, the steel ball could descend onto the center of the coronal root end and contact the radicular dentin without contacting the filling material. The maximum force leading to fracture was recorded in Newton $(\mathrm{N})$ and the data was statistically analyzed.

Six single rooted maxillary central incisors were selected and root canal preparation was performed in a similar way to that of fracture resistance testing. Then the teeth were randomly divided into two groups $(n=3)$ based on obturating material used. In group I, root canals were obturated with ProRoo MTA and in group II, root canals were obturated with OrthoMTA III in a similar way to that of fracture resistance testing. All the specimens were stored at $37^{\circ}$ $\mathrm{C}$ and $100 \%$ relative humidity for $48 \mathrm{~h}$ for the complete set of the cement. Each root was then horizontally sectioned with a slow-speed, watercooled diamond saw (Isomet 2000; Buehler) to produce discs of approximately $2 \mathrm{~mm}$ thick per specimen. Then each slice was further cut into two halves with the help of an orthodontic wire cutter (Hu-Friedy). Care was taken to avoid the displacement of the obturating material from the root canal walls. These semicircular sections were then dehydrated using ascending grades of ethyl alcohol (25\%, 50\%, 75\% and 100\%) for $15 \mathrm{~min}$. The samples were then mounted 
on metallic stubs, gold sputtered using an ion sputter, and interface of the root canal wall and the obturation material was examined under SEM (JEOL) at X10000 and 10KV to observe for the intratubular biomineralization.

Group comparison was done using Kruskal Wallis test and inter group comparison was performed using Mann Whitney test with SPSS software (SPSS Inc.). The significance level was preset at $\alpha=0.05$.

\section{RESULTS}

\section{Fracture resistance testing}

The mean value of fracture resistance for OrthoMTA III was found to be the maximum and the positive control group had the minimum value (Table I and Figure 1). Kruskal Wallis test revealed that there was a significant difference between experimental groups tested $(\mathrm{p}<0.001)$. On intergroup comparison using Mann Whitney test, positive control group demonstrated the least fracture resistance, while OrthoMTA III group showed the highest fracture resistance. There was no significant difference between negative control group and ProRoot MTA group $(\mathrm{p}=0.821)$.

Table I - Mean and Standard Deviation values of fracture resistance of different experimental groups.

\begin{tabular}{|cccccc|}
$\begin{array}{c}\text { Experimental } \\
\text { groups }\end{array}$ & N & Mean & $\begin{array}{c}\text { Std. } \\
\text { Deviation }\end{array}$ & Minimum & Maximum \\
$\begin{array}{c}\text { Positive } \\
\text { control }\end{array}$ & 10 & $122.565^{\mathrm{a}}$ & 20.321 & 105.760 & 172.640 \\
\hline $\begin{array}{c}\text { Negative } \\
\text { control }\end{array}$ & 10 & $355.415^{\mathrm{b}}$ & 50.004 & 250.220 & 410.220 \\
\hline Proroot MTA & 10 & $365.494^{\mathrm{b}}$ & 88.588 & 249.590 & 514.400 \\
\hline OrthoMTA III & 10 & $608.776^{\mathrm{c}}$ & 123.947 & 488.490 & 928.610 \\
\hline
\end{tabular}

Similar superscript letters in the column indicate that there was no statistical difference between the groups, different superscript letters indicate statistically significant difference ( $p$ «0.05).

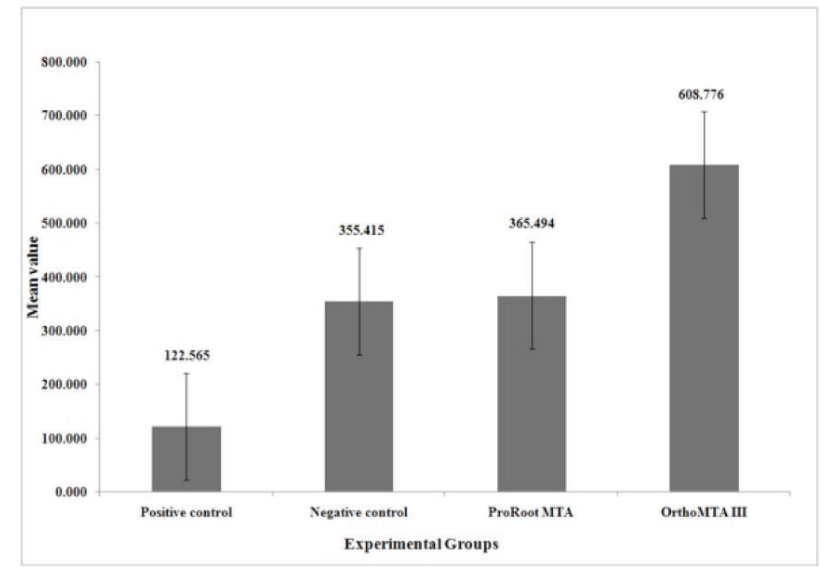

Figure 1 - Mean fracture strength of teeth obturated with different types of MTA cements.

\section{SEM evaluation}

The scanning electron microscopic images of root canals obturated with OrthoMTA III showed formation of apatite crystals densely packing the dentinal tubules. On the other hand, root canals obturated with ProRoot MTA showed the minimum dentinal tubular biomineralization with apatite crystals sparsely clogging the dentinal tubules (Figure 2).

\section{Mode of fracture}

Representative samples showing different mode of fractures in all the experimental groups are shown in Figure 3. In the positive control group, five samples had incomplete oblique fracture and the remaining five samples had complete oblique fracture. In the negative control group, 8 specimens had incomplete oblique fracture and 2 specimens had complete oblique fracture. In ProRoot MTA group, 8 specimens had complete oblique fracture and 2 specimens had incomplete oblique fracture. In OrthoMTA group, 8 specimens had incomplete oblique fractures and 2 specimens had complete vertical root fracture. 


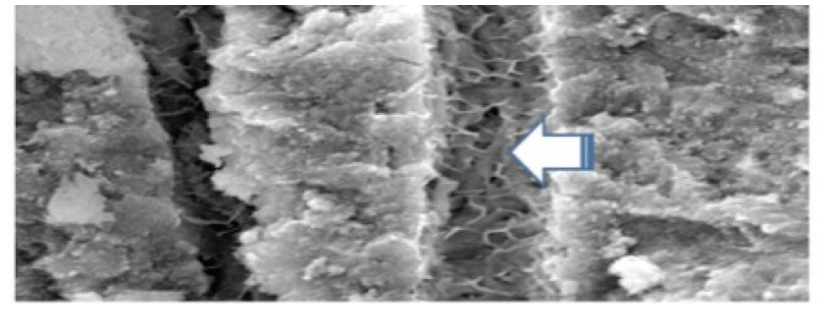

OrthoMTAIII

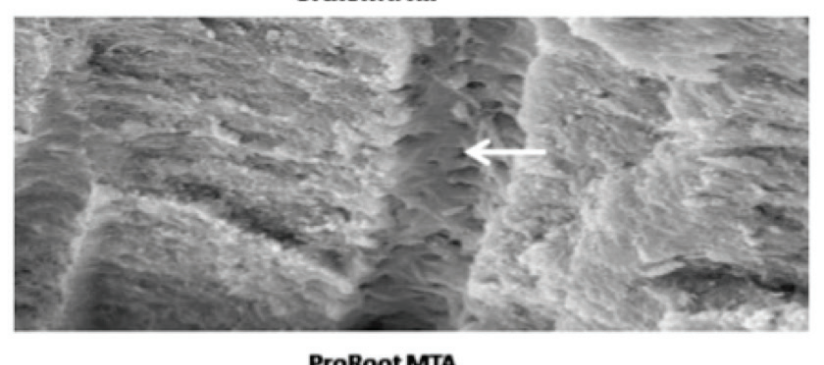

ProRoot MTA

Figure 2 - Representative high resolution scanning electron microscopy images of biomineralization of dentinal tubules in teeth obturated with OrthoMTA III and ProRoot MTA cements. In orthoMTA III group, the dentinal tubules were densely packed with petals like precipitate of minerals (thick arrow). In ProRoot MTA group, there were minimal precipitated crystals within the dentinal tubule (thin arrow).

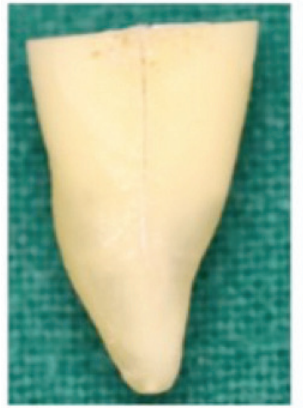

A

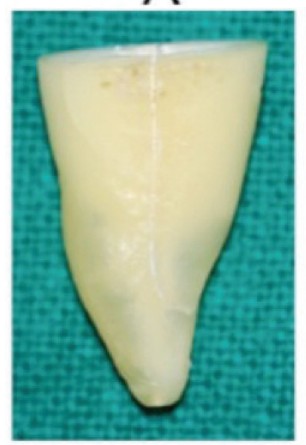

C

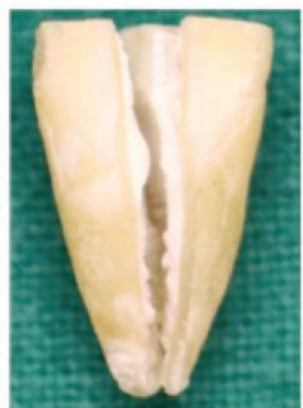

B

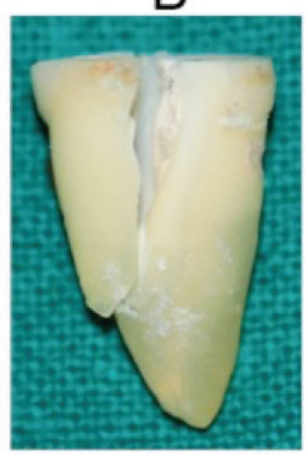

D
Figure 3 - a-d Representative samples showing different mode of fractures. a) Incomplete vertical root fracture; b) Complete vertical root fracture; c) Incomplete oblique root fracture; d) Complete oblique root fracture.

\section{DISCUSSION}

The results of the present study demonstrated that, fracture resistance of teeth obturated with OrthoMTA III was much more when compared to ProRoot MTA. Hence, the null hypothesis stating that there was no influence of both the obturating materials on the fracture resistance of root canal treated teeth has to be rejected. Fracture resistance of endodontically treated teeth has been studied extensively by various in-vitro studies [26-28]. In the present study, the better performance of OrthoMTA III may be attributed to the different setting mechanism between the two cements.

During the OrthoMTA III setting reaction, high $\mathrm{pH}$ will be decreased to almost neutral value. As the result of this reaction, enough end product of water $(\mathrm{H} 2 \mathrm{O})$ can be produced and supply the humidity to dentin through dentinal tubules. The toughness of dentin in the hydrated state is significantly higher than in the dehydrated state [29]. Earlier studies have suggested that, the fluid filled dentinal tubules could function to hydraulically transfer and dissipate the occlusal forces applied to teeth [30,31]. From the perspective of theoretical mechanics, the structural stability of dentine is a function of mineralization and of moisture content [32]. The presence of water in the hydrated dentine resulted in a stress strain response characteristic of tough material, while the loss of free water resulted in stiffening and response characteristic of brittle material [33].

The removal of the pulp, pathological and iatrogenic changes to dentin, and the rate limiting barrier to fluid by enamel and cementum should logically affect the degree of hydration over time. Approximately $75 \%$ of the water in dentin is in the tubules and the remainder is in the mineralized matrix [34]. It was also shown that, rehydration of dentin can completely reverse the dehydration induced strains and water level in dentine. The 
water lost during this dehydration process was mostly the 'free' or 'loosely' bound water that fills the dentinal tubules and the root canals $[35,36]$. It is important to realize that, the free water that fills the dentinal tubules and root canal lumen can form a three dimensional interconnecting channel system of water, which along with the hydrostatic pressure creates a preexisting tensile stresses and strains in the loading direction, which counteracts the compressive loads due to biting acting on the bulk dentin structure [37].

Long time calcium hydroxide $[\mathrm{Ca}(\mathrm{OH}) 2]$ intracanal medicament will weaken the dentin dramatically and cause the root fracture [38]. One of end products of hydration of MTA is $\mathrm{Ca}(\mathrm{OH}) 2$. Initial $\mathrm{pH}$ of ProRoot MTA is 12.5 . This high alkaline $\mathrm{pH}$ is enough to dissolve the collagen matrix of the dentin. In vitro, the humidity condition and high $\mathrm{pH}$ is sustained for a long time. However, in-vivo environment, high $\mathrm{pH}$ value will decrease due to CDHA formation in the presence of phosphorous ion in the body fluid. Hydration equation of OrthoMTA III consumes $\mathrm{Ca}(\mathrm{OH}) 2$ and finally $\mathrm{pH}$ will be decreased to neutral. Therefore, it may prevent the weakening of dentin after its application.

Another reason for the better fracture resistance of OrthoMTA III when compared to negative control and ProRoot MTA groups may be due to the interfacial bonding between MTA and root canal dentin walls. OrthoMTA III showed the better biomineralization effect under current conditions. This enhanced biomineralization effect may induce the stronger interfacial bonding. In both the experimental groups, petalslike precipitates were formed within the dentinal tubules. However, the amount of precipitate was higher with OrthoMTA III group when compared to ProRoot MTA. This finding could be attributed to the small particle size (nono size) of OrthoMTA III which would have contributed to induce more stable precursors for guiding an effective diffusion of the ions than the higher molecular weight particles of ProRoot MTA [39]. Also, the nano particle size of OrthoMTA III provides initial advantages in compressive and flexural strengths [40]. The better fracture resistance of specimens obturated with OrthoMTA III was also seen with respect to the mode of fracture. The majority of the specimens in the OrthoMTA III group had incomplete oblique root fracture demonstrating a better interfacial bonding of OrthOMTA III cement to the root canal walls, when compared to ProRoot MTA, in which majority of the samples had complete oblique root fracture.

PDL is an important structure for distribution of stresses to the teeth generated by occlusal load [41]. Hence, simulation of the PDL plays an essential role in the fracture pattern. In the present study, to simulate the clinical scenario, a PDL simulation model was employed as suggested by Soares et al. [42] Acrylic resin was used as the embedding material for the teeth since it has been shown to be capable of reproducing the bone to withstand compressive and tangential forces during mastication. A lightbody condensation silicone impression material was used to simulate the periodontal ligament, since its modulus of elasticity is close to that of human PDL [43].

In the present study, PBS pretreatment before final obturation was performed to enhance the intratubular mineralization of both the MTA cements. It has been reported that, the preconditioning with the phosphate ions derived from PBS induces the nucleation formation, which is known as polymer-induced liquid precursor (PILP) process and enhance the formation of the prenucleation cluster and its subsequent crystal growth [44]. Phosphate ions in PBS are considered to make the intratubular environment even more labile in PILP process, and enhance the formation of the prenucleation cluster and its subsequent crystal growth.

Different studies have used varying techniques of transmission of force to the teeth [45-48]. In the present study, the technique 
published by Madarati et al. [49] was employed, in which a 4-mm-diameter steel ball attached to a steel cylinder was used to create a wedging effect eventually leading to fracture of the teeth.

Standard irrigation protocol of $\mathrm{NaOCl}$ and a chelating agent to remove the smear layer formed during instrumentation was employed in this study [50]. However, 7\% maleic acid (MA) was used to remove smear layer instead of 17\% EDTA which is commonly used chelating agent because, various studies have demonstrated that, 7\% MA removes canal wall smear layer more efficiently than $17 \%$ EDTA $[51,52]$.

\section{CONCLUSION}

From this study, the following conclusions were drawn:

1. Root canals obturated with OrthoMTA III had better fracture resistance and increased tubular biomineralization than ProRoot MTA;

2. Endodontically treated teeth which needs reinforcement can be obturated with OrthoMTA III.

\section{Conflict of interest}

The authors did not have any commercial interest in any of the materials used in this study.

\section{REFERENCES}

1. Gher ME Jr, Dunlap RM, Anderson MH, Kuhl LV. Clinical survey of fractured teeth. J Am Dent Assoc. 1987;114(5):174-7.

2. Meister FJr, Lommel TJ, Gerstein H. Diagnosis and possible causes of vertical root fractures. Oral Surg Oral Med Oral Pathol. 1980;49(3):243-53.

3. Sornkul E, Stannard JG. Strength of roots before and after endodontic treatment and restoration. J Endod. 1992;18(9):440-3.

4. Lee KW, Williams MC, Camps JJ, Pashley DH. Adhesion of endodontic sealers to dentin and gutta-percha. J Endod 2002;28(10):684-8.

5. Lertchirakarn V, Palamara JE, Messer HH. Load and strain during lateral condensation and vertical root fracture. J Endod. 1999;25(2):99-104.

6. Saw LH, Messer HH. Root strains associated with different obturation techniques. J Endod. 1995;21(6):314-20.

7. Ross RS, Nicholls Jl, Harrington GW. A comparison of strains generated during placement of five endodontic posts. J Endod. 1991;17(9):450-6.
8. Tay FR, Pashely DH. Monoblocks in root canals- a hypothetical or a tangible goal. JEndod. 2007;33(4):391-8.

9. Vizgirda PJ, Liewehr FR, Patton WR, McPherson JC, Buxton TB. A comparison of laterally condensed gutta-percha, thermoplasticized guttapercha, and mineral trioxide aggregate as root canal filling materials. $J$ Endod. 2004;30(2):103-6.

10. Venturi M, Breschi L. Evaluation of apical filling after warm vertical guttapercha compaction using different procedures. J Endod. 2004;30(6):43640.

11. Torabinejad M, Chivian N. Clinical applications of mineral trioxide aggregate. J Endod 1999;25:197-205.

12. Schmitt D, Lee J, Bogen G. Multifaceted use of ProRoot MTA root canal repair material. Pediatr Dent. 2001;23(4):326-30.

13. White JD, Lacefield WR, Chavers LS, Eleazer PD. The effect of three commonly used endodontic materials on the strength and hardness of root dentin. J Endod. 2002;28(12):828-30.

14. Andreasen J0, Munksgaard EC, Bakland LK. Comparison of fracture resistance in root canals of immature sheep teeth after filling with calcium hydroxide or MTA. Dent Traumatol. 2006;22(3):154-6.

15. Bortoluzzi EA, Souza EM, Reis JM, Esberard RM, TanomaruFilho M. Fracture strength of bovine incisors after intraradicular treatment with MTA in an experimental immature tooth model. Int Endod J. 2007;40:684-91.

16. Hatibovic-Kofman S, Raimundo L, Zheng L, Chong L, Friedman $\mathrm{M}$, Andreasen JO. Fracture resistance and histological findings of immature teeth treated with mineral trioxide aggregate. Dent Traumatol. 2008;24(3):272-6 doi: 10.1111/j.1600-9657.2007.00541.X.

17. Chang SW, Baek SH, Yang HC, Seo DG, Hong ST, Han SH, et al. Heavy metal analysis of ortho MTA and ProRoot MTA. J Endod. 2011;37(12):1673-6. Doi:10.1016/j.joen.2011.08.020.

18. Lee BN, Son HJ, Noh HJ, Koh JT, Chang HS, Hwang IN, et al. Cytotoxicity of newly developed ortho MTA root-end filling materials. JEndod. 2012;38(12):1627-30. doi:10.1016/j.joen.2012.09.004.

19. Kum KY, Zhu Q, Safavi K, Gu Y, Bae KS, Chang SW. Analysis of six heavy metals in Ortho mineral trioxide aggregate and ProRoot mineral trioxide aggregate by inductively coupled plasma-optical emission spectrometry. Aust Endod J. 2013;39(3):126-30. doi: 10.1111/j.1747.2012.00349.x.

20. Yoo JS, Chang SW, Oh SR, Perinpanayagam H, Lim SM, Yoo YJ, et al. Bacterial entombment by intratubular mineralization following orthograde mineral trioxide aggregate obturation: a scanning electron microscopy study. Int J Oral Sci. 2014;6(4):227-32. doi: 10.1038/ijos.2014.30.

21. Yoo JS, Chang SW, Oh SR, Perinpanayagam H, Lim SM, Yoo YJ, et al. Bacterial entombment by intratubular mineralization following orthograde mineral trioxide aggregate obturation: a scanning electron microscopy study. Int J Oral Sci. 2014;6(4):227-32. doi: 10.1038/ijos.2014.30.

22. El Briak-benabdeslam H, Ginebra MP, Vert M, Boudeville P. Wet or dry mechanochemical synthesis of calcium phosphates? Influence of the water content on DCPD-CaO reaction kinetics. Acta Biomater. 2008,4(2):378-86.

23. Sarkar NK, Caicedo R, Ritwik P, Moiseyeva R, Kawashima I. Physicochemical basis of the biologic properties of mineral trioxide aggregate. J Endod. 2005;31(2):97-100.

24. Bozeman TB, Lemon RR, Eleazer PD. Elemental analysis of crystal precipitate from gray and white MTA. J Endod. 2006;32(5):425-8. 
25. Soares CJ, Pizi EC, Fonseca RB, Martins LR. Influence of root embedment material and periodontal ligament simulation on fracture resistance tests. Braz Oral Res. 2005;19(1):11-6.

26. Hammad M, Qualtrough A, Silikas N. Effect of new obturating materials on vertical root fracture resistance of endodontically treated teeth. J Endod. 2007;33(6):732-6

27. Hatibovic-Kofman S, Raimundo L, Zheng L, Chong L, Friedman M, Andreasen JO. Fracture resistance and histological findings of immature teeth treated with mineral Trioxide aggregate. Dent Traumatol. 2008;24(3):272-6. doi: 10.1111/.j.1600-9657.2007.00541.X.

28. Bortoluzzi EA, Souza EM, Reis JM, Esberard RM, Tanomaru-Filho M Fracture strength of bovine incisors after intra-radicular treatment with MTA in an experimental immature tooth model. Int Endod J. 2007;40(9):684-91.

29. Kruzic JJ, Nalla RK, Kinney JH, Ritchie RO. Crack blunting, crack bridging and resistance-curve fracture mechanics in dentin: effect of hydration. Biomaterials 2003;24(28):5209-21

30. Pashley DH. Dentin permeability. In: Spangberg LSW, editor. Experimental endodontics. Boca Raton: CRS Press; 1990. p. $19-49$.

31. Hirata K, Nakashima M, Sekine I, Mukouyama Y, Kimura K. Dentinal fluid movement associated with loading of restorations. J Dent Res. 1991;70(6):975-8.

32. Kinney JH, Balooch M, Marshall GW, Marshall SJ. Atomic-force microscopic study of dimensional changes in human dentine during drying. Arch Oral Biol. 1993;38(11):1003-7.

33. Kishen A, Asundi A. Experimental investigation on the role of water in the mechanical behavior of structural dentine. J Biomed Mater Res A. 2005;73(2):192-200.

34. van der Graaf ER, ten Bosch JJ. The uptake of water by freeze-dried human dentine sections. Arch Oral Biol. 1990;35(9):731-9.

35. Jameson MW, Hood JA, Tidmarsh BG. The effects of dehydration and on some mechanical properties of human dentine. JBiomech. 1993:26(9):1055-65

36. Kishen A, Rafique A. Investigations on the dynamics of water in the macrostructural dentine. J Biomed Opt. 2006;11(5):054018.

37. Kishen A, Vedantam S. Hydromechanics in dentine: role of dentinal tubules and hydrostatic pressure on mechanical stress-strain distribution. Dent Mater. 2007;23(10):1296-306

38. Andreasen J0, Farik B, Munksgaard EC. Long-term calcium hydroxide as a root canal dressing may increase risk of root fracture. Dent Traumatol. 2002;18(3):134-7.

39. Huang SC, Naka K, Chujo Y. Effect of molecular weights of poly(acrylic acid) on crystallization of calcium carbonate by the delayed addition method. Polym J. 2008; 40:154-62
40. Ha WN, Kahler B, Walsh LJ. The influence of particle size and curing conditions on testing mineral trioxide aggregate cement. Acta Biomater Odontol Scand. 2016,2(1):130-7. doi: 10.1080/23337931.2016.1239181.

41. Rees JS. An investigation into the importance of the periodontal ligament and alveolar bone as supporting structures in finite element studies. J Oral Rehab. 2001;28(5):425-32

42. Soares CJ, Pizi EC, Fonseca RB, Martins LRM. Influence of root embedment material and periodontal ligament simulation on fracture resistance tests. Braz Oral Res. 2005;19(1):11-6.

43. Yoshida N, Koga Y, Peng CL, Tanaka E, Kobayashi K. In vivo measurement of the elastic modulus of the human periodontal ligament. Med Eng Phys. 2001;23(8):567-72

44. Gower LB. Biomimetic model systems for investigating the amorphous precursor pathway and its role in biomineralization. Chem Rev. 2008:108(11):4551-627.doi: 10.1021/cr800443h.

45. Hammad M, Qualtrough A, Silikas N. Effect of new obturating materials on vertical root fracture resistance of endodontically treated teeth. J Endod. 2007:33(6):732-6.

46. Andreasen JO, Munksgaard EC, Bakland LK. Comparison of fracture resistance in root canals of immature sheep teeth after filling with calcium hydroxide or MTA. Dent Traumatol. 2006;22(3):154-6.

47. Hatibovi c-Kofman S, Raimundo L, Zheng L, Chong L, Friedman $\mathrm{M}$, Andreasen JO. Fracture resistance and histological findings of immature teeth treated with mineral Trioxide aggregate. Dent Traumatol. 2008;24(3):272-6. doi:10.1111/j.1600-9657.2007.00541.X

48. Bortoluzzi EA, Souza EM, Reis JM, Esberard RM, Tanomaru-Filho M. Fracture strength of bovine incisors after intra-radicular treatment with MTA in an experimental immature tooth model. Int Endod J. 2007:40(9):684-91

49. Madarati AA, Qualtrough AJ, Watts DC. Effect of retained fractured instruments on tooth resistance to vertical fracture with or without attempt at removal. Int Endod J. 2010;43(11):1047-53. doi: 10.1111/j.13652591.2010.01783.x.

50. Zehnder M. Root canal irrigants. J Endod. 2006;32(5):389-98.

51. Ballal NV, Kandian S, Mala K, Bhat KS, Acharya S. Comparison of the efficacy of maleic acid and ethylenediaminetetraacetic acid in smear layer removal from instrumented human root canal: A scanning electron microscopic study. J Endod. 2009;35(11):1573-6. doi:10.1016/j. joen.2009.07.021

52. Ulusoy Ol, Görgül G. Effects of different irrigation solutions on root dentine microhardness, smear layer removal and erosion. Aust Endod J. 2013;39(2):66-72. doi: 10.1111/j.1747-4477.2010.00291.x.

Prof. Dr. Mutlu Özcan (Corresponding address)

University of Zurich, Center for Dental and Oral Medicine, Plattenstrasse 11, CH 8032, Zurich, Switzerland.

E-mail: mutluozcan@hotmail.com

Date submitted: 2020 Jan 05

Accept submission: 2020 Apr 03 